\title{
A new stereoselective approach to a selectively protected derivative of D-pinitol and its evaluation as $\alpha$-L-rhamnopyranose mimetic ${ }^{1}$
}

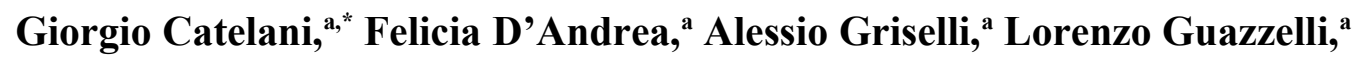 \\ Laura Legnani, ${ }^{\text {b }}$ Lucio Toma ${ }^{\text {b, }}$ \\ ${ }^{a}$ Dipartimento di Chimica Bioorganica e Biofarmacia, Università di Pisa, Via Bonanno, 33 - I-56126, Pisa (Italy) \\ ${ }^{b}$ Dipartimento di Chimica Organica, Università di Pavia, Via Taramelli, 10 - I-27100, Pavia (Italy)
}

\begin{abstract}
The synthesis of 3,5-di-O-benzyl-D-pinitol has been stereoselectively accomplished through intramolecular aldolization of 2,6-di-O-benzyl-4- $O$-methyl-L-lyxo-hexos-5-ulose followed by reduction with $\mathrm{NaBH}(\mathrm{OAc})_{3}$. Computational analysis [DFT calculations at the B3LYP/6-31G(d) level] suggests that D-pinitol in water largely prefers the conformation corresponding to the ${ }^{1} \mathrm{C}_{4}$ one of a $\alpha$-L-rhamnopyranoside unit, being thus a good candidate for its mimicking.
\end{abstract}

Keywords: D-Pinitol; $\alpha$-L-rhamnopyranose mimetic; Intramolecular aldol condensation; Computational analysis

D-Pinitol is an interesting member of the natural methoxylated inositol family and has been recognized for its anti-diabetic properties, ${ }^{2}$ and, more recently, for the ability to modulate the immune response by interacting with dendritic cells (DCs) maturation. ${ }^{3}$ Furthermore, the access to selectively protected D-pinitol derivatives represents an important task in view of the synthesis of potential antitumor agents as (+)-pancratistatin ${ }^{4}$ and some carbocyclic azole nucleoside analogues. ${ }^{5}$ Owing to the formal analogy between inositol derivatives and monosaccharides, it could also be possible to substitute a specific member of one family with an appropriate one of the other family, maintaining not only the overall structural requirements but also the biological properties. In fact, some examples are reported in which modified monosaccharides, easily available in pure enantioform, have been used to substitute D-myo-inositol frames. ${ }^{6}$ However, to the best of our knowledge, the reverse replacing possibility has not yet been exemplified although the class of carbasugars, ${ }^{7}$ in which a methylene group replaces the ring oxygen atom, constitutes one of the most popular type of carbohydrate mimetics. ${ }^{8}$

Looking to the relative orientation of D-pinitol (1) hydroxyl groups, we suppose $\mathbf{1}$ to be a possible candidate for mimicking a $\alpha$-L-rhamnopyranose unit (2), that is present in several bio-active complex saccharides as, for instance, the capsular polysaccharide repeating unit of some Pneumococcus strains. ${ }^{9}$

Before planning the synthesis of suitably protected D-pinitol derivatives, a preliminary computational exploration of the conformational space of $\mathbf{1}$ and $\mathbf{2}$ was carried out through DFT calculations at the B3LYP/6-31G(d) level. ${ }^{10}$ A high number of starting geometries were prepared, taking in consideration all the degrees of conformational freedom of the molecules. In particular, in the case of $\mathbf{2}$, the two chair pyranose

\footnotetext{
"Authors for correspondence. G.C.: phone +39 050 2219678, fax +39 050 2219660, e-mail giocate@,farm.unipi.it; L.T.: phone +390382 987843, fax +390382987323, e-mail lucio.toma@unipv.it
} 
forms ${ }^{1} \mathrm{C}_{4}$ and ${ }^{4} \mathrm{C}_{1}$ were investigated (Chart), together with the different orientations of the four hydroxyl groups, with particular attention to the formation of intramolecular hydrogen bonds.

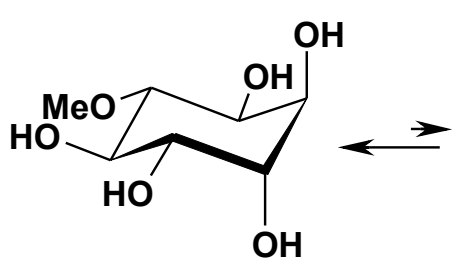

1- ${ }^{-}$- $^{\text {like }}$

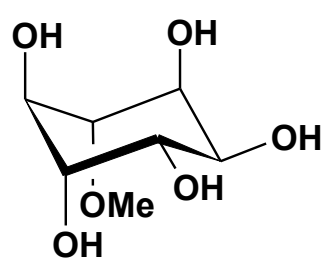

1-4 C $^{-}$like

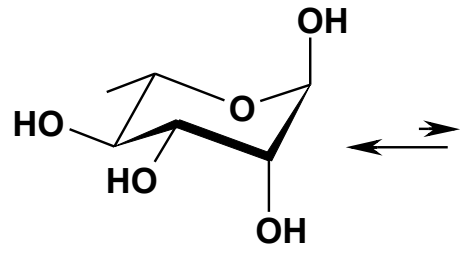

${ }^{2-1} C_{4}$

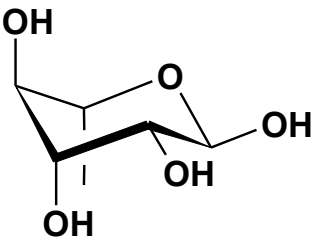

$2-{ }^{4} C_{1}$

Chart

Also for compound 1 ring inversion was investigated considering the ${ }^{1} \mathrm{C}_{4}$-like and ${ }^{4} \mathrm{C}_{1}$-like conformations (Chart). In this case, in addition to the orientation of the hydroxyl groups, the conformational preferences of the methoxy group were considered through the evaluation of its three different gauche and anti orientations. The energies of the optimized conformers were recalculated in water by single point calculations, at the same level as above, using the polarizable continuum model $\mathrm{PCM}^{11}$ to take into account the influence of the solvent and their percentage contribution to the overall population was determined at $298 \mathrm{~K}$ through the Boltzmann equation. The conformations of each compound were grouped in two families, characterized by the ring geometry; the global minimum of compounds $\mathbf{2}$ and $\mathbf{1}$ was a member of the ${ }^{1} \mathrm{C}_{4}$ and the ${ }^{1} \mathrm{C}_{4}$-like family, respectively, while the lowest energy inverted conformation resulted higher in energy by about 3 and 4 $\mathrm{kcal} / \mathrm{mol}$, respectively. Considering the entire families, L-rhamnopyranose (2) showed a complete preference for the ${ }^{1} \mathrm{C}_{4}$ geometry, being the overall population of the ${ }^{4} \mathrm{C}_{1}$ family $<1 \%$. Analogously, D-pinitol (1) showed a high preference for the ${ }^{1} \mathrm{C}_{4}$-like geometry which resulted populated for $>98 \%$.

Considering these conformational results, we approached the synthesis of 1 through a sequence (Scheme) based on the intramolecular aldol condensation of a partially protected aldohexos-5-ulose, that recently was successfully used ${ }^{12}$ for the stereoselective synthesis of protected inositol derivatives. Starting material for the synthesis was the known 1,5-methyl bis-glycoside 3, masked form of the 2,6-di-O-benzyl-L-arabino-hexos-5ulose, readily obtained from commercially available methyl $\beta$-D-galactopyranoside through a previously described synthetic route. ${ }^{13}$ The transformation of compound 3 into 4 , having the sole $\mathrm{OH}-3$ group in the free form, was achieved efficiently with a three step strategy (88\% overall yield) involving: 1) the preliminary protection of the equatorial OH-3 group of 3 through a regioselective stannylidene acetal mediated naphtylmethylation $\left(\mathrm{Bu}_{2} \mathrm{SnO}, \mathrm{PhCH}_{3}\right.$ under azeotropic anhydrification followed by $\mathrm{NAPBr}$ and $\left.\mathrm{Bu}_{4} \mathrm{NBr}\right) ; 2$ ) the methylation of $\left.\mathrm{OH}-4\left(\mathrm{CH}_{3} \mathrm{I}, \mathrm{DMF}, \mathrm{NaH}\right) ; 3\right)$ the final selective removal of the naphtylmethyl group with DDQ in $\mathrm{CH}_{3} \mathrm{CN}-\mathrm{H}_{2} \mathrm{O}$. 


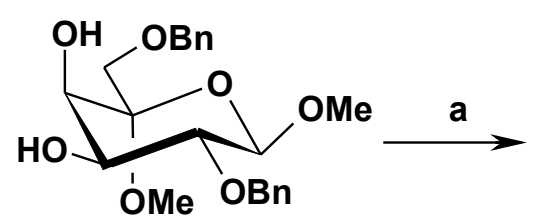

3

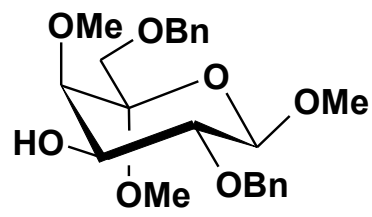

4
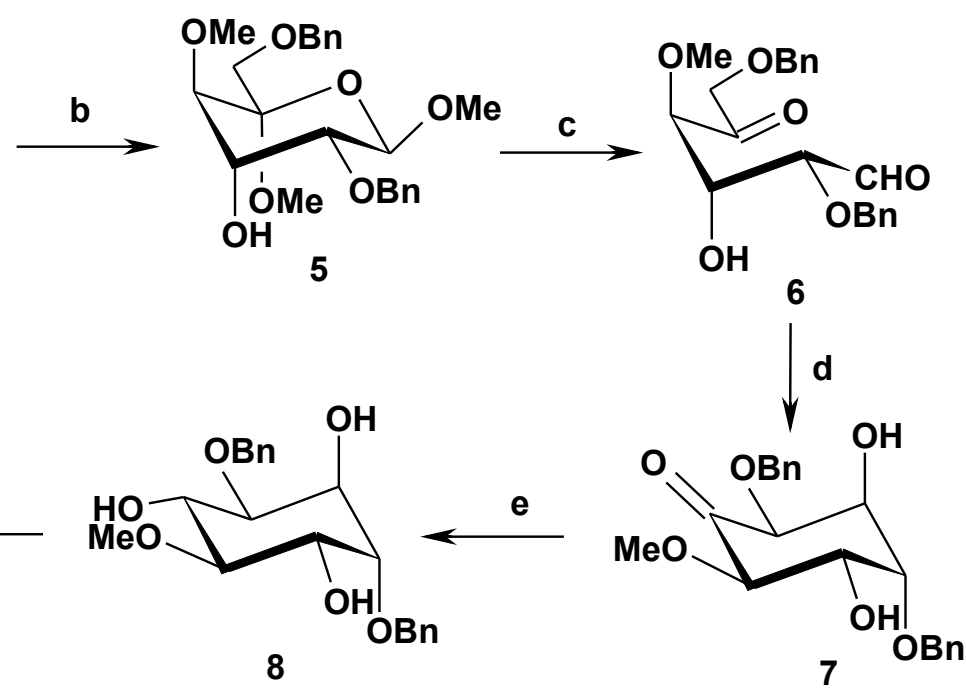

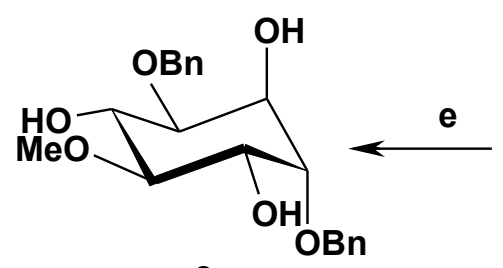

8

1 (D-pinitol)

Scheme. Reagents and conditions: (a) (1) $\mathrm{Bu}_{2} \mathrm{SnO}, \mathrm{NAPBr}, \mathrm{CH}_{3} \mathrm{Ph}$; (2) $\mathrm{CH}_{3} \mathrm{I}, \mathrm{DMF}$, NaH; (3) DDQ, $\mathrm{CH}_{3} \mathrm{CN}-\mathrm{H}_{2} \mathrm{O}$ (88\%, overall yield). (b) (1) TPAP, $\mathrm{NMO}, \mathrm{CH}_{2} \mathrm{Cl}_{2}$; (2) $\mathrm{NaBH}_{4}, \mathrm{MeOH}$, (84\%, over two steps). (c) $90 \%$ aq. $\mathrm{CF}_{3} \mathrm{COOH} / 4: 1 \mathrm{CH}_{3} \mathrm{CN}-\mathrm{H}_{2} \mathrm{O}$. (d) $\mathrm{DBU}$, $\mathrm{CH}_{2} \mathrm{Cl}_{2}$, $51 \%$ or $\mathrm{Et}_{3} \mathrm{~N}, \mathrm{Yb}(\mathrm{OTf})_{3}, \mathrm{CH}_{2} \mathrm{Cl}_{2}, 62 \%$. (e) $\mathrm{NaBH}(\mathrm{OAc})_{3}, \mathrm{CH}_{3} \mathrm{CN}-\mathrm{AcOH}, 75 \%$. (f) $\mathrm{H}_{2}, \mathrm{Pd} / \mathrm{C}, \mathrm{MeOH}$, quantitative yield.

The C-4 epimerization of the derivative 4 was made with a two step procedure requiring first the oxidation with the TPAP-NMO system in $\mathrm{CH}_{2} \mathrm{Cl}_{2}$ followed by the crude uloside intermediate reduction $\left(\mathrm{NaBH}_{4} / \mathrm{MeOH}\right.$, r.t.). The 1,5-bis-methyl glycoside 5, masked form of the 2,6-di- $O$-benzyl-4- $O$-methyl-L-lyxo-hexos-5-ulose $\mathbf{6}$, was obtained in high yield after chromatographic purification ( $84 \%$ yield over two steps). The complete diastereoselectivity of the reaction could be reasonably attributed to the presence of the axial 5-OMe which allows the hydride to attack only on the $\beta$ face shielding the $\alpha$ one. The bis-glycoside 5 was then submitted to acid hydrolysis $\left(\mathrm{CF}_{3} \mathrm{COOH}\right.$, in 4:1 $\left.\mathrm{CH}_{3} \mathrm{CN}-\mathrm{H}_{2} \mathrm{O}\right)$ giving the 1,5-dicarbonylic derivative 6 as a complex mixture of tautomeric forms. Although the NMR spectra of this compound were not interpreted, its structure was firmly proved by the next reaction. Crude 6 was subjected to an intramolecular aldol condensation under conditions ( 0.2 eq of $\mathrm{DBU}$ in $\mathrm{CH}_{2} \mathrm{Cl}_{2}$ ) analogous to those previously reported for similar reactions of 5-ketoaldohexoses, ${ }^{12}$ giving with complete diastereoselectivity the inosose 7 isolated after flash chromatography in $51 \%$ yield. Interestingly, when the intramolecular aldolization was performed with $\mathrm{Et}_{3} \mathrm{~N}$ in presence of $\mathrm{Yb}(\mathrm{OTf})_{3}$ in $\mathrm{CH}_{2} \mathrm{Cl}_{2}$ the isolated yield of 7 increased to $62 \%$. The inosose 7 was then reduced with $\mathrm{NaBH}(\mathrm{OAc})_{3}$ under standard condition $\left(\mathrm{CH}_{3} \mathrm{CN}, \mathrm{AcOH}\right)$ and brought to the expected di-O-benzyl-D-pinitol derivative 8 in $76 \%$ yield. This complete stereoselectivity takes place through an internal hydride delivery as described by Evans for $\beta$-hydroxy ketones. ${ }^{14}$

Compounds 4-5 and 7-8 were characterized and their analytical ${ }^{15}$ and NMR data, ${ }^{16}$ determined by $1 \mathrm{D}$ and 2D (COSY and HETCOR) NMR experiments, were in agreement with the proposed structures. Finally the Dpinitol (1) was obtained in nearly quantitative yield by hydrogenolysis of $\mathbf{8}$ over $10 \%$ palladium on charcoal in $\mathrm{MeOH}$. The physico-chemical properties and NMR data of 1 were identical to those reported. ${ }^{17}$ The high field $(600 \mathrm{MHz}){ }^{1} \mathrm{H}-\mathrm{NMR}$ spectrum in $\mathrm{D}_{2} \mathrm{O}$ confirms the calculated conformational preferences of the compound; in 
particular, the high value of the $J_{l, 2}(9.9 \mathrm{~Hz}), J_{l, 6}(9.6 \mathrm{~Hz})$, and $J_{5,6}(9.9 \mathrm{~Hz})$ and the low value of the $J_{2,3}(2.8$ $\mathrm{Hz})$, and $J_{4,5}(2.9 \mathrm{~Hz})$ establish four substituents in equatorial position for the preferred conformer.

Our next efforts will be oriented to understand if D-pinitol is truly able to mimic a $\alpha$-L-rhamnopyranose unit, in view of the synthesis of pseudotrisaccharide derivatives of the structure $\beta$-D-ManNAcp-(1 $\rightarrow 4)-\alpha-\mathrm{D}-\mathrm{Glc} p$ $(1 \rightarrow 4)$-D-pinitol-3-O- $\mathrm{PO}_{3}{ }^{2-}$, representing a chemically more stable mimic of the capsular polysaccharide repeating unit of Streptococcus pneumoniae $19 F$.

\section{Acknowledgements}

This research was supported by a grant from MiUR (Ministero dell'Università e della Ricerca, Roma) in the frame of the national project COFIN 2006.

\section{References and notes}

1. Part 23 of the series "Chemical Valorisation of Milk-Derived Carbohydrates". For Part 22 see Ref 18.

2. Fonteles, M.C.; Huang, L.C.; Larner, L. J. Diabetologia 1996, 39, 731-734; (b) Ortmeyer, H.K., Huang, L.C.; Zhang, L.; Hansen, B.C.; Larner, L. Endocrinology 1993, 132, 646-651.

3. Lee, J.S.; Jung, I.D.; Jeong, Y.-I.; Lee, C.-M.; Shin, Y.K.; Lee, S.-Y.; Suh, D.-S.; Yoon, M.-S.; Lee, K.-S.; Choi, Y.H.; Chung, H.Y.; Park, Y.-M. Int. Immunopharm. 2007, 7, 791-806.

4. Li, M.; Wu, A.; Zou, P. Tetrahedron Lett. 2006, 47, 3707-3710.

5. Zhan, T.; Lou, H. Carbohydr. Res. 2007, 342, 865-869.

6. (a) Moitessier, N.; Chrétien, F.; Chapleur, Y.; Humeau, C. Tetrahedron Lett. 1995, 36, 8023-8026; (b) Roussel, F.; Hilly, M.; Chrétien, F.; Mauger, J.-P.; Chapleur, Y. J. Carbohydr. Chem. 1999, 18, 697-707; (c) Chrétien, F.; Roussel, F.; Hilly, M.; Mauger, J.-P.; Chapleur, Y. J. Carbohydr. Chem. 2005, 24, 549-581; (d) Dinev, Z.; Gannon, T.C.; Egan, C.; Watt, J.A.; McConville, M.J.; Williams, S.J. Org. Biomol. Chem. 2007, 5, 952-959; (e) Rosenberg, H.J.; Riley, A.M.; Marwood, R.D.; Correa, V.; Taylor, C.W.; Potter, B.V.L. Carbohydr. Res. 2001, 332, 53-66; (f) Abe, H.; Shuto, S.; Matsuda, A. J. Org. Chem. 2000, 65, 4315-7325. 7. Arjona, O.; Gomez, A., M.; Lopez, J., C.; Plumet, J. Chem. Rev. 2007, 107, 1919-2036.

8. (a) Carbohydrate Mimics: Concepts and Method, Chapleur, Y. Ed., Wiley-VCH Publ. 1998; (b) Sears, P.;Wong, C.-H. Angew. Chem. Int. Ed. 1999, 38, 2301-2324.

9. (a) Jennings, H. J. Adv Carbohydr. Chem. Biochem. 1983, 41, 155; (b) Pozsgay, V. Adv. Carbohydr. Chem. Biochem. 2001, 56, 153.

10. (a) Becke, A.D. J. Chem. Phys. 1993, 98, 5648-5652; (b) Lee, C.; Yang, W.; Parr, R.G. Phys. Rev. B 1988, $37,785-789$.

11. Barone, V.; Cossi, M.; Tomasi, J. J. Comput. Chem. 1998, 19, 404-417.

12. a) Pistarà, V.; Barili, P.L.; Catelani, G.; Corsaro, A.; D’Andrea, F.; Fisichella, S. Tetrahedron Lett. 2000, 41, 3253-3256; (b)

Catelani, G.; Corsaro, A.; D’Andrea, F.; Mariani, M.; Pistarà, V. Bioorg. Med. Chem. Lett. 2002, 12, 3313-3315.

13. Barili, P.L.; Berti, G.; Catelani, G.; D’Andrea, F. Gazz. Chim. Ital. 1992, 48, 135-142.

14. Evans, D.A.; Chapman, K.T.; Carreira, E.M. J. Am. Chem. Soc. 1988, 110, 3560-3578.

15. Compound 4: syrup, (Found: C, 66.34; H, 7.37; $\mathrm{C}_{23} \mathrm{H}_{30} \mathrm{O}_{7}$ requires: C, 66.01; H, 7.23); $\mathrm{R}_{\mathrm{f}} 0.26(7: 3 \mathrm{hexane} / \mathrm{EtOAc})$; $[\alpha]_{\mathrm{D}}-34.6(c$ 1.2, $\mathrm{CHCl}_{3}$ ); compound 5: syrup, (Found: $\mathrm{C}, 66.25 ; \mathrm{H}, 7.34 ; \mathrm{C}_{23} \mathrm{H}_{30} \mathrm{O}_{7}$ requires: $\left.\mathrm{C}, 66.01 ; \mathrm{H}, 7.23\right)$; $\mathrm{R}_{\mathrm{f}} 0.16(7: 3 \mathrm{hexane} / \mathrm{EtOAc})$; $\left.\alpha\right]_{\mathrm{D}}$ -58.5 (c 1.2, $\mathrm{CHCl}_{3}$ ); compound 7: white solid, (Found: $\mathrm{C}, 67.88 ; \mathrm{H}, 6.63 ; \mathrm{C}_{21} \mathrm{H}_{24} \mathrm{O}_{6}$ requires: $\mathrm{C}, 67.73 ; \mathrm{H}, 6.50$ ); mp 113-115 ${ }^{\circ} \mathrm{C}$ (EtOAc); $\mathrm{R}_{\mathrm{f}} 0.22$ (4:6 hexane/EtOAc); $[\alpha]_{\mathrm{D}}-1.7\left(c\right.$ 1.1, $\left.\mathrm{CHCl}_{3}\right)$; compound 8: white solid, (Found: $\mathrm{C}, 67.51 ; \mathrm{H}, 7.09 ; \mathrm{C}_{21} \mathrm{H}_{26} \mathrm{O}_{6}$ requires: $\mathrm{C}, 67.36 ; \mathrm{H}, 7.00)$; $\mathrm{mp} 91-94{ }^{\circ} \mathrm{C}(\mathrm{EtOAc}) ; \mathrm{R}_{\mathrm{f}} 0.14\left(2: 8\right.$ hexane/EtOAc); $[\alpha]_{\mathrm{D}}+12.3\left(c 1.1, \mathrm{CHCl}_{3}\right)$.

16. Selected NMR data: compound 4: $\delta_{\mathrm{H}}\left(\mathrm{CD}_{3} \mathrm{CN}, 250 \mathrm{MHz}\right) 4.39\left(\mathrm{~d}, 1 \mathrm{H}, J_{1,2}=7.6 \mathrm{~Hz}, \mathrm{H}-1\right), 3.86\left(\mathrm{ddd}, 1 \mathrm{H}, J_{2,3}=9.8 \mathrm{~Hz}, J_{3,4} 3.4 \mathrm{~Hz}\right.$, $J_{3, O H}=6.7 \mathrm{~Hz}, \mathrm{H}-3$ ), 3.58, 3.53 (AB syst., 2H, $J_{A, B}=10.3 \mathrm{~Hz}, \mathrm{H}-6 \mathrm{a}, \mathrm{H}-6 \mathrm{~b}$ ), 3.48, 3.45 (2s, each 3H, OMe-1, OMe-4), 3.43 (d, 1H, H-4), $3.33(\mathrm{dd}, 1 \mathrm{H}, \mathrm{H}-2), 3.23$ (s, 3H, OMe-5), 3.12 (d, 1H, OH-3); $\delta_{\mathrm{C}}\left(\mathrm{CD}_{3} \mathrm{CN}, 62.9 \mathrm{MHz}\right) 101.6(\mathrm{C}-1), 101.5(\mathrm{C}-5), 80.7(\mathrm{C}-4), 80.6$ (C-2), 71.5 (C-3), 66.4 (C-6), $61.9(\mathrm{OMe}-4), 57.1(\mathrm{OMe}-1), 48.5(\mathrm{OMe}-5)$; compound 5: $\delta_{\mathrm{H}}\left(\mathrm{CD}_{3} \mathrm{CN}, 250 \mathrm{MHz}\right) 4.72\left(\mathrm{~d}, 1 \mathrm{H}, J_{1,2}=8.1\right.$ $\mathrm{Hz}, \mathrm{H}-1), 4.12$ (dt, 1H, $\left.J_{3,4}=J_{2,3}=3.5 \mathrm{~Hz}, J_{3, \mathrm{OH}}=9.1 \mathrm{~Hz}, \mathrm{H}-3\right), 3.55$ (s, 2H, H-6a, H-6b), 3.49 (s, 3H, OMe-1), 3.41 (d, 1H, H-4), 3.38 (dd, 1H, H-2), 3.35 (s, 3H, OMe-4), 3.32 (s, 3H, OMe-5), 3.31 (d, 1H, OH-3); $\delta_{\mathrm{C}}\left(\mathrm{CD}_{3} \mathrm{CN}, 62.9 \mathrm{MHz}\right) 103.4$ (C-5), 98.2 (C-1), 78.9 (C-4), 76.2 (C-2), 73.9, 68.5 (C-3), 66.9 (C-6), 59.4 (OMe-4), 56.1 (OMe-1), $48.8(\mathrm{OMe}-5)$; compound 7: $\delta_{\mathrm{H}}\left(\mathrm{CD} \mathrm{CN}_{3}, 250 \mathrm{MHz}\right)$ $4.37\left(\mathrm{dd}, 1 \mathrm{H}, J_{2,3}=3.5 \mathrm{~Hz}, J_{2,6}=1.1 \mathrm{~Hz}, \mathrm{H}-2\right), 4.28\left(\mathrm{q} \mathrm{sl}, 1 \mathrm{H}, J_{3,4}=3.5 \mathrm{~Hz}, J_{3, O H}=3.4 \mathrm{~Hz}, \mathrm{H}-3\right), 3.98$ (dd, $\left.1 \mathrm{H}, J_{5,6}=9.7 \mathrm{~Hz}, \mathrm{H}-6\right), 3.90$ $\left(\mathrm{dd}, 1 \mathrm{H}, J_{4,5}=3.4 \mathrm{~Hz}, \mathrm{H}-4\right), 3.83\left(\mathrm{ddd}, 1 \mathrm{H}, J_{5, O H}=6.7 \mathrm{~Hz}, \mathrm{H}-5\right), 3.53(\mathrm{~d}, 1 \mathrm{H}, \mathrm{OH}-3), 3.44(\mathrm{~s}, 3 \mathrm{H}, \mathrm{OMe}), 3.43(\mathrm{~d}, 1 \mathrm{H}, \mathrm{OH}-5) ; \delta_{\mathrm{C}}$ $\left(\mathrm{CD}_{3} \mathrm{CN}, 62.9 \mathrm{MHz}\right) 204.6(\mathrm{C}-1), 86.2(\mathrm{C}-6), 81.1(\mathrm{C}-2), 79.4(\mathrm{C}-4), 73.5(\mathrm{C}-5), 71.3(\mathrm{C}-3), 59.4(\mathrm{OMe})$; compound 8: $\delta_{\mathrm{H}}(\mathrm{CDCl}$, $250 \mathrm{MHz}) 4.65,4.553 .98\left(\mathrm{t}, 1 \mathrm{H}, J_{2,3}=J_{3,4}=3.1 \mathrm{~Hz}, \mathrm{H}-3\right), 3.88(\mathrm{~m}, 2 \mathrm{H}, \mathrm{H}-4, \mathrm{H}-5), 3.80\left(\mathrm{t}, 1 \mathrm{H}, J_{1,2}=J_{1,6}=9.2 \mathrm{~Hz}, \mathrm{H}-1\right), 3.61(\mathrm{~s}, 3 \mathrm{H}$, OMe), 3.60 (dd, 1H, H-2), 3.30 (t sl, $\left.1 \mathrm{H}, J_{5,6}=9.0 \mathrm{~Hz}, \mathrm{H}-6\right) ; \delta_{\mathrm{C}}\left(\mathrm{CDCl}_{3}, 62.9 \mathrm{MHz}\right) 83.2(\mathrm{C}-6), 79.4(\mathrm{C}-2), 78.8(\mathrm{C}-4), 72.0(\mathrm{C}-1)$, 70.5 (C-5), 66.8 (C-3), 60.5 (OMe).

17. (a) Mondal, D.N.; Barik, B.R.; Dey, A.K.; Kundu, A.B.; Banerji, A.; Maiti, S. J. Indian Chem. Soc. 1993, 70, 651-652; (b) Sridhar, C.; Krishnaraju, A.V.; Subbaraju, G.V. Indian J. Pharm. Sci. 2006, 68, 111-114.

18. Attolino, E.; Bonaccorsi, F.; Catelani, G.; D’Andrea, F.; Krenek, K,; Bezouska, K.; Kren, V. J. Carbohydr. Chem. 2008, $27,000$. 